\title{
Why Physicians Participate in Executions
}

TO THE EDITOR: In his discussion of why some physicians participate in executions (March 23 issue), ${ }^{1}$ Gawande makes contradictory and thus unpersuasive statements. Although he believes that "some human beings . . . do such evil as to deserve to die," he still would like "a legal ban on the participation of physicians ... in executions." His reason, that "the medical assistance provided primarily serves the government's purposes," overlooks the reality that in the United States, "the government" is us and prisoners are executed by "we the people." I do not personally favor, nor do I participate in, executions, but until the law changes, I believe we owe it to the condemned to ensure that they die quickly and painlessly; doing so serves the interests of both the prisoner and society.

Gawande also says "the government actively subverts core ethical principles of medical practice." How so? Government merely asks physicians to make an independent decision to help; there is no coercion whatsoever.

Finally, the guidelines of the American Medical Association (AMA) are equally illogical. Their policy that pronouncing death is unethical but certifying it is ethical seems a rationalized distinction without a difference.

Lawrence I. Bonchek, M.D.

Lancaster General Hospital

Lancaster, PA 17603

1. Gawande A. When law and ethics collide - why physicians participate in executions. N Engl J Med 2006;354:1221-9.

TO THE EDITOR: The AMA forbids physicians to participate in executions or to pronounce death - unless someone else has pronounced it first. This is analogous to shaking one's head at a hanging while watching it occur. Accepting capital punishment in principle means accepting it in practice, whether by the hand of a physician or anyone else. If one approves of capital punishment in principle (as I do), then one must accept its practical consequences. If one finds the practice too brutal, one must either reject it in principle or seek to mitigate its brutality. If one chooses the latter option, then the participation of physicians seems more humane than delegating the deed to prison wardens, for by condoning the participation of untrained people who could inflict need- less suffering that we physicians might have prevented, we are just as responsible as if we had inflicted the suffering ourselves. The AMA position should be changed either to permit physician participation or to advocate the abolition of capital punishment. The hypocritical attitude of "My hands are clean - let the spectacle proceed" only leads to needless human suffering.

Bruce E. Ellerin, M.D., J.D.

New York University School of Medicine

New York, NY 10016

bee2@nyu.edu

TO THE EDITOR: Gawande refers to the cases of Timothy McVeigh and Saddam Hussein to support the view that capital punishment can be justified. However, the first concern should be not the number of people allegedly murdered by the suspect but the probability that the suspect actually committed the crime. Between 1995 and 2005, 741 people were executed in the United States, and there are at least six well-documented cases of wrongful executions. ${ }^{1}$

Physicians demand great stringency from a diagnostic process. An obvious reason is that treatment (such as chemotherapy) may cause harm and may even be lethal. In these circumstances, specific tests are applied. A murder trial may be viewed as a diagnostic process. If the consequence of the verdict is the death penalty, which has an associated mortality of 100 percent, we do not understand why a physician should abandon the strong ethical standards in matters of life and death that humanity expects from medicine. In view of the moderate specificity of the justice system, we do not believe it is justifiable for a physician to support capital punishment.

Cornelis Kramers, M.D., Ph.D.

Jaap Deinum, M.D., Ph.D.

Radboud University Nijmegen Medical Center

6525GA Nijmegen, the Netherlands

c.kramers@pharmtox.umcn.nl

1. Death Penalty Information Center. Additional innocence information: executed but possibly innocent. (Accessed June 15, 2006, at http://www.deathpenaltyinfo.org/article.php?scid=6\& did=111\# executed.)

TO THE EDITOR: Lethal injection is not designed to be a humane method of execution; it is designed to appear to be a humane method of execution. 
Why else would there be a need for pancuronium when the dose of either thiopental or potassium alone would be lethal? The pancuronium ensures that a person in severe pain cannot demonstrate this fact to witnesses.

A humane method of execution is an oxymoron. The deliberate killing of a human being is always a brutal and violent act. The argument that the death penalty deters murder is so discredited that death-penalty supporters do not even bother to make it anymore. Therefore, the only justification for the death penalty is a desire for vengeance. Death-penalty supporters want to have their cake and eat it too. They wish to satisfy their bloodlust but still claim to be humane. By participating in executions, physicians would merely help them to achieve this end.

Robert J. Yaes, M.D., Sc.D.

15 Quantum Place

Gaithersburg, MD 20877

TO THE EDITOR: The position of the AMA is clear that participation of physicians in executions in any way is unethical, and this stance has been endorsed by state medical societies, boards of medical examiners, and all medical organizations that have taken a position on the subject. What is lamentable is the absence of disciplinary sanctions against licensees. As Gawande points out, physicians who violate this ethical precept almost always hide their identity, and states help them do so. I suspect that many of the 17 states that require physician participation actually honor that requirement in the breach, since it is getting harder to find willing physicians. For a 2001 execution in New Mexico - the only execution carried out in the state during the past 45 years - an execution team was imported from Texas, and the names, titles, and qualifications of its members were kept secret. When law and ethics collide, the law should be changed.

Steven S. Spencer, M.D.

2154 Calle de Sebastian

Santa Fe, NM 87505

DR. GAWANDE REPLIES: Bonchek does not perceive a conflict between a physician's core com- mitment (and oath) to serve the interests of human beings as individual persons and serving the purposes of the government by assisting in the execution of human beings. He further argues that there is little reason to be concerned about the use of physicians for governmental purposes, since we live in a democracy - the purposes of the government are therefore our purposes as a people, he says. These are odd positions to take. If the government asks us to perform medical procedures against a person's wishes and interests, the ethical problem ought to be clear - and knowing that the request is "the people's will" does not erase it. Some persons may commit evils so terrible that they morally forfeit their right to live, but as physicians we nonetheless have a commitment not to use our skills for punishment. That is the conundrum I sought to grapple with. I concluded that society's need for doctors to stay true to the fundamental principles of the profession should be paramount. When the government mandates that a punishment must involve physician participation, however, and it provides anonymity, money, and protections against challenges to the physician's licensure in order to achieve it, it is difficult to see how this is not active subversion of those principles.

The letters from Bonchek and Ellerin also criticize the ethics code of the AMA that permits a physician to certify death (i.e., to sign a death certificate) after an execution but not to pronounce death. The AMA is capable of defending itself. I will just point out that the AMA ethics code forbids physicians from attending an execution in a medical capacity for any purpose pronouncing death, signing a death certificate, or otherwise. It permits only signing a death certificate (or performing an autopsy) in a medical setting. ${ }^{1}$ The act is in this way notably distinct from pronunciation of death at an execution.

Atul Gawande, M.D., M.P.H.

Harvard School of Public Health

Boston, MA 02115

1. Council on Ethical and Judicial Affairs. 1992 Code of medical ethics: current opinions. Chicago: American Medical Association, 1992. 